\title{
NUTRITIONAL VALUE, VITAMINS, SUGARS AND AROMA VOLATILES IN NATURALLY FERMENTED AND DRY KVASS
}

\author{
Ivo Lidums*, Daina Karklina, Asnate Kirse, Martins Sabovics \\ Department of Food Technology, Faculty of Food Technology, Latvia University of Agriculture, 22 Rigas iela, Jelgava, Latvia, \\ *e-mail:ivo@ilm.lv
}

\begin{abstract}
Naturally fermented rye bread kvass is a seasonal product with a pronounced rye bread flavour having the highest demand during hot summer days. However, non-pasteurised and non-filtered kvass has a very short shelf-life. There are numerous benefits of drying to extend kvass shelf-life, however it can have a significant influence on the product composition and quality. The aim of this research was to assess and compare nutritional value, vitamins, sugars and aroma volatiles in naturally fermented and spray dried kvass. Naturally fermented non-pasteurised, non-filtered bread kvass was used to produce dry kvass at the University of Warmia and Mazury in Olsztyn, Poland. Maltodextrin was used in $25 \%$ quantity to kvass dry matter in order to aid the spray drying process. Nutritional value of liquid kvass (7\% solids) and dry kvass (powder, 93\% solids) was determined according to EU Regulation 1169/2011, B vitamins - according to AOAC $986.27\left(\mathrm{~B}_{1}\right)$, AOAC $970.65\left(\mathrm{~B}_{2}\right)$ and AOAC $961.14\left(\mathrm{~B}_{3}\right)$. Content of sugars was determined using high performance liquid chromatography, whereas aroma volatiles were assessed using solid phase microextraction in combination with gas chromatography/mass spectrometry. Drying process had a significant influence on the content of B vitamins in kvass; the highest decrease was observed for niacin (vitamin $\mathrm{B}_{3}$ ). The content of major sugars was lower in dry kvass based on the dilution by the addition of maltodextrin. Totally 26 different volatile compounds were detected in liquid and dry kvass, total values of peak areas were significantly lower in dry kvass $(p<0.05)$.
\end{abstract}

Keywords: kvass, spray drying, micronutrients, volatile compounds.

\section{Introduction}

Soft drinks are in the diet of consumers throughout their lives, and the choice of the product depends on the taste of the drink, its impact on the health, national traditions and market trends. Kvass is a non-alcoholic beverage that can be used without restriction, as its effects on the human body are similar to kefir; furthermore, the energy value of naturally fermented kvass is approx. $1 / 2$ less than of typical non-alcoholic beverages (Lidums et al., 2014). Due to the favourable microflora composition (lactic acid bacteria, yeast), kvass is enriched with B vitamins, lactic acid and carbon dioxide which is a product of incomplete alcoholic and lactic acid fermentation (Omasheva et al., 2015).

Naturally fermented non-pasteurised and non-filtered rye bread kvass is a seasonal product with a pronounced rye bread flavour and a very short shelf-life. Similar to dry juices (juice powders), the benefits of drying to extend kvass shelf-life are reduced volume or weight, less packaging, easier handling and transport. Therefore, dry naturally fermented kvass could be a valuable contribution in comparison with liquid kvass. There are several drying methods, but spray drying is one of the techniques used to produce dry powders. Spray drying is the transformation of the substance of the liquid or slurry to dry powdery substance. The liquid product is atomized into a chamber where the resulting spray mixes with hot gas, which evaporates the liquid component of the spray leaving dried particles (Goula, Adamopoulos, 2010). Drying, however, can have a significant influence on the product composition and quality, thus, it is important to investigate the effect of drying technological processes.

Recently Lidums and Karklina (2016) investigated the possibilities of dry kvass application in food flavour enrichment and concluded that milk candy 'Gotina', icecream 'Plombir', biscuits, meringue cookies, éclair filling and cupcakes can be supplemented with dry kvass with good sensory and physico-chemical outcomes. The aim of this research was to assess and compare nutritional value, vitamins, sugars and aroma volatiles in naturally fermented and spray dried kvass.

\section{Materials and Methods}

Experimental design

The object of the research was liquid and dry kvass. Kvass samples were analysed at:

- Latvian Certification centre, Ltd. - nutritional value of kvass,

O Institute of Biology, University of Latvia - content of B vitamins,

O Department of Chemistry, Latvia University of Agriculture - content of sugars,

○ Department of Food Technology, Latvia University of Agriculture - aroma volatiles.

Naturally fermented non-pasteurised, non-filtered bread kvass from Liepzeme Ltd. (water, rye bread rusks $10 \%$ (rye flour, wheat flour, sugar, rye malt, salt, yeast, barley malt extract, caraway), sugar, barley malt, wheat malt, acidifier: citric acid, yeast) was used to produce dry kvass by spray drying as described by Lidums et al. (2016). Dry kvass was obtained at the Institute of Process Engineering and Equipment, The University of Warmia and Mazury in Olsztyn, Poland.

Kvass was atomized from a rotary atomizer (disk speed $11000 \mathrm{rpm}$ ) into a vertical co-current drying chamber with inlet and outlet air temperatures of $170{ }^{\circ} \mathrm{C}$ and $103{ }^{\circ} \mathrm{C}$, respectively; temperature inside the drying chamber was $75-80^{\circ} \mathrm{C}$. Maltodextrin was used in $25 \%$ quantity to kvass dry matter in order to aid the spray drying process. 
Determination of nutritional value and calculation of energy value

Nutritional composition of liquid and dry kvass samples was determined according to standard methods: protein content (ISO 5983-1:2005), fat and saturated fatty acid content (ISO 12966-4:2015), sugar content by Bertrand's method (Chidan et al., 2011), sodium content (ISO 7485:2000), ethanol content (ГОСТ 6687.7-88) and moisture content (ISO 5537:2004). Carbohydrates (\%) were determined by difference (FAO, 2003) according to formula:

$$
C=100-(m+p+l+a),
$$

where $\mathrm{C}$ - carbohydrates, $\%, \mathrm{~m}$ - moisture content, $\mathrm{p}$ - protein content, $\%, 1-$ lipid content, $\%$, a - ash content, $\%$.

Energy value of liquid and dry kvass samples was calculated according to coefficients described in EU Regulation No 1169/2011: carbohydrates $17 \mathrm{~kJ} \mathrm{~g}^{-1}$; protein $17 \mathrm{~kJ} \mathrm{~g}^{-1}$, fat $37 \mathrm{~kJ} \mathrm{~g}^{-1}$ and ethanol $29 \mathrm{~kJ} \mathrm{~g}^{-1}$.

\section{Determination of $B$ vitamins}

Vitamin $\mathrm{B}_{1}$ was determined by the fluorometric method (AOAC 986.27), which is based on the oxidation of thiamine to thiochrome, followed by measurement of fluorescence intensity. Vitamin $\mathrm{B}_{2}$ was determined by the fluorometric method (AOAC 970.65), which is based on fluorescence measurement of riboflavin after acid and enzymatic hydrolysis. Vitamin $\mathrm{B}_{3}$ was determined by the colorimetric method (AOAC 961.14), which is based on the König reaction with cyanogen bromide.

\section{Determination of sugar content}

The content of fructose, glucose and maltose was determined using high performance liquid chromatography (HPLC) method (Shimadzu LC 20 Prominence) according to Lidums et al. (2016). Identification of sugars in liquid and dry kvass was done by comparing retention times of individual sugars in the reference vs. tested solution (qualitative analysis).

\section{Detection of aroma volatiles}

Volatile compounds were determined in liquid and dry kvass samples using solid phase micro-extraction (SPME) in combination with gas chromatography/mass spectrometry (GC/MS) according to the method described by Lidums et al. (2015). The SPME fibre was coated with a thin bipolar polymer film Carboxen/Polydimethylsiloxane (CAR/PDMS). The film thickness was $85 \mu \mathrm{m}$ with bipolar polarity (Supelco, Inc., USA). The process consisted of heating the samples to release volatile compounds above the liquid phase and absorb them onto the CAR/PDMS fibre. Then volatile compounds from the fibre were thermally desorbed in GC/MS injector and transferred to the capillary column for separation. Compounds were identified by comparison of their mass spectra with mass spectral library Nist98 and the amount of compounds was measured as peak area units (PAU).
Data analysis

The obtained data processing was performed with the Microsoft Excel 13 for Windows; mean values and standard deviations were calculated. t-test and Tukey's test were used for data cross-comparison. For the interpretation of the results it was assumed that $\alpha=0.05$ with $95 \%$ confidence.

\section{Results and Discussion}

The characteristics of naturally fermented nonpasteurised and non-filtered rye bread kvass were evaluated in two products - liquid and dry form of kvass. Kvass and similar products have been produced before, whereas dry kvass was produced and investigated for the first time. The comparison was carried out on dry weight basis, except for nutritional composition and aroma volatiles.

Nutritional value of naturally fermented and dry kvass Dry kvass had a higher energy value than naturally fermented kvass on fresh weight basis (Table 1). Dry kvass contains only traces of ethanol contrary to kvass, as alcohol evaporates during drying process (USDA Table of Nutrient Retention Factors).

Table 1

Nutritional and energy value of naturally fermented and dry kvass

\begin{tabular}{lcc}
\hline \multicolumn{1}{c}{ Parameters } & $\begin{array}{c}\text { Liquid } \\
\text { kvass }\end{array}$ & $\begin{array}{c}\text { Dry } \\
\text { kvass }\end{array}$ \\
\hline Dry matter, \% & $7.00 \pm 0.02$ & $93.00 \pm 0.04$ \\
Protein content, g 100 g-1 & $0.15 \pm 0.02$ & $1.90 \pm 0.10$ \\
Fat content, g 100 g & $<0.10$ & $<0.10$ \\
of which saturates, g 100 g-1 & $<0.01$ & $<0.10$ \\
Carbohydrate content, g 100 g- & $5.90 \pm 0.02$ & $75.20 \pm 0.21$ \\
of which sugars, g 100 g-1 & $4.70 \pm 0.02$ & $61.30 \pm 0.15$ \\
Sodium content, mg 100 g-1 & $0.16 \pm 0.01$ & $2.10 \pm 0.05$ \\
Ethanol content, vol \% & $1.20 \pm 0.03$ & $<0.10$ \\
Energy value, $\mathrm{kJ} \mathrm{100} \mathrm{g-1}$ & 130.40 & 1285.77 \\
\hline
\end{tabular}

$B$ vitamins in naturally fermented and dry kvass Drying process had a significant influence on the content of B vitamins in kvass (Table 2); the highest decrease was observed for niacin (vitamin $B_{3}$ ).

Table 2

Content of $B$ vitamins in kvass samples, mg $100 \mathrm{~g}^{-1} \mathrm{DW}$

\begin{tabular}{lcc}
\hline Vitamins & Liquid kvass & Dry kvass \\
\hline Thiamine $\left(\mathrm{B}_{1}\right)$ & $0.71 \pm 0.09$ & $0.25 \pm 0.02$ \\
Riboflavin $\left(\mathrm{B}_{2}\right)$ & $1.28 \pm 0.12$ & $0.48 \pm 0.02$ \\
Niacin $\left(\mathrm{B}_{3}\right)$ & $18.14 \pm 0.48$ & $4.36 \pm 0.12$ \\
\hline
\end{tabular}

A kinetic analysis of the thermodegradation process on $\mathrm{B}$ vitamins showed that these vitamins are thermolabile (Fuliaş et al., 2014), and the decrease after thermal processing can account to $60 \%$ (Asadullah et al., 2010). Several authors have reported the reduction of water-soluble vitamins after spray drying (Grabowskia et al., 2008; Abubakar, Jega, 2010), besides the addition of maltodextrin decreased the 
overall kvass solids together with the amount of B vitamins in dry kvass.

\section{Sugar content in naturally fermented and dry kvass}

Major sugars in kvass were fructose and glucose, both kvass samples also contained significant amount of maltose (Table 3). The content of major sugars was higher in liquid kvass. Barba et al. (2014) showed that drying process caused a significant decrease in the reducing sugars content which was associated with Maillard's reactions. However, Grabowskia et al. (2008) reported that spray dried sweet potato powder with the addition of maltodextrin showed lower content of sugars compared to sweet potato puree, based on the dilution by the addition of maltodextrin.

Table 3

Sugars in kvass samples, g $100 \mathrm{~g}^{-1} \mathrm{DW}$

\begin{tabular}{lcc}
\hline Sugars & Liquid kvass & Dry kvass \\
\hline Fructose & $25.13 \pm 0.19$ & $15.83 \pm 0.12$ \\
Glucose & $21.76 \pm 0.14$ & $14.31 \pm 0.17$ \\
Maltose & $8.26 \pm 0.11$ & $6.12 \pm 0.07$ \\
\hline
\end{tabular}

Therefore, we conclude that the decrease of fructose, glucose and maltose in dry kvass can be accounted to the addition of maltodextrin as drying aid, which increases glass transition temperature and improves product stability (Tonon et al., 2011; Oberoi, Sogi, 2015).

Aroma volatiles in naturally fermented and dry kvass A total of 26 different aroma volatile compounds were isolated and characterized by GC-MS analysis. The identified volatile compounds belong to esters, alcohols, acids, aldehydes and ketones. A more various volatile compound profile was found for naturally fermented kvass. 19 volatile compounds were identified in naturally fermented kvass with the total sum of peak area $-19.16 \times 10^{7}$ PAU. The total sum of peak area $\left(11.81 \times 10^{7} \mathrm{PAU}\right)$ in dry kvass was approx. $40 \%$ lower than in liquid kvass $(\mathrm{p}<0.05)$, a total of 15 volatile compounds were present in dry kvass (Table 4). The highest value of peak area $\left(10.05 \times 10^{7}\right)$ among all detected volatile compounds was detected for 4-penten2-ol (alcohol) in naturally fermented kvass, which gives fruity aroma, which is in agreement with a previous research by Lidums et al. (2015), whereas in dry kvass the amount of 4-penten-2-ol was about 7 times lower. Carvone had the second highest peak area $\left(2.28 \times 10^{7}\right)$ in naturally fermented kvass, but it was not present in dry kvass. According to Sedláková et al. (2003), carvone and limonene form the main portion of essential oils in caraway fruits, which are an ingredient in the rye bread used for naturally fermented kvass production. Salim et al. (2015) reported that drying affected the reduction of carvone in spearmint.

A significant amount of ethyl octanoate $\left(1.03 \times 10^{7}\right)$ was found in naturally fermented kvass, resulting in fruit and fat odour. The three aroma volatiles with the highest peak area values in dry kvass were hexanal, 4-penten-2-ol and benzaldehyde, forming green, fruity, bitter and almond odours, respectively.
Volatile compounds found in both liquid and dry kvass samples form base aroma profile which includes fruity (4-penten-2-ol), green (hexanal), sour (acetic acid), bread, almond, sweet (furfural), burnt (furfuryl alcohol), fatty type (hexanoic acid), floral type (benzylalcohol), rose (phenylethylalcohol), sweat, cheese (octanoic acid) aroma.

Table 4

Volatile compounds $\left(\mathrm{PAU} \times \mathbf{1 0}^{\mathbf{7}}\right)$ in liquid and dry kvass samples

\begin{tabular}{|c|c|c|c|}
\hline $\begin{array}{l}\text { Volatile } \\
\text { compounds }\end{array}$ & Odour* & $\begin{array}{c}\text { Liquid } \\
\text { kvass }\end{array}$ & $\begin{array}{c}\text { Dry } \\
\text { kvass }\end{array}$ \\
\hline 4-penten-2-ol & fruity & 10.05 & 1.39 \\
\hline Hexanal & green & 0.59 & 3.04 \\
\hline 3-methyl-butanal & $\begin{array}{l}\text { chocolate, } \\
\text { peach, fatty }\end{array}$ & - & 0.10 \\
\hline 2-pentylfuran & fruity & - & 0.68 \\
\hline 1-pentanol & fermented & - & 0.17 \\
\hline $\begin{array}{l}\text { 3-hydroxy-2- } \\
\text { butanone }\end{array}$ & butter, cream & - & 0.22 \\
\hline 1-octen-3-ol & mushroom & - & 0.50 \\
\hline Acetic acid & sour & 0.58 & 0.98 \\
\hline Furfural & $\begin{array}{l}\text { bread, } \\
\text { almond, } \\
\text { sweet }\end{array}$ & 0.03 & 0.62 \\
\hline Benzaldehyde & $\begin{array}{l}\text { bitter, } \\
\text { almond }\end{array}$ & - & 1.56 \\
\hline Furfuryl alcohol & burnt & 0.17 & 0.72 \\
\hline Hexanoic acid & fatty type & 0.07 & 0.41 \\
\hline Benzylalcohol & floral type & 0.55 & 0.66 \\
\hline $\begin{array}{l}\text { Phenylethyl } \\
\text { alcohol }\end{array}$ & rose & 0.26 & 0.35 \\
\hline Maltol & caramel & - & 0.21 \\
\hline Octanoic acid & sweat, cheese & 0.30 & 0.21 \\
\hline Carvone & caraway & 2.28 & - \\
\hline Ethyl decanoate & waxy type & 0.60 & - \\
\hline Decanoic acid & rancid, fat & 0.19 & - \\
\hline $\begin{array}{l}\text { 2-phenylethyl } \\
\text { acetate }\end{array}$ & $\begin{array}{l}\text { rose, honey, } \\
\text { tobacco }\end{array}$ & 0.59 & - \\
\hline $\begin{array}{l}\text { 3-methyl-1- } \\
\text { butanol }\end{array}$ & $\begin{array}{l}\text { whiskey, } \\
\text { malt, burnt }\end{array}$ & 0.70 & - \\
\hline Isoamyl acetate & banana & 0.63 & - \\
\hline Ethyl caproate & $\begin{array}{l}\text { fruity, green, } \\
\text { pineapple, } \\
\text { sweet }\end{array}$ & 0.28 & - \\
\hline Hexyl acetate & sweet, fruity & 0.12 & - \\
\hline Heptyl acetate & green & 0.05 & - \\
\hline 2-ethyl-1-decanol & - & 0.08 & - \\
\hline Ethyl octanoate & fruit, fat & 1.03 & - \\
\hline
\end{tabular}

*Gas chromatography - olfactometry of natural products (2004); Odor Descriptors (2015)

Volatile compounds found in kvass samples are associated with the roasting of geminated grains (malt production), bread baking and the metabolism of yeast cells during fermentation process as argued by 
Hazelwood et al. (2008), Purlis (2010), Birch et al. (2013) and Riu-Aumatell et al. (2014).

\section{Conclusions}

Dry kvass had a higher energy value than naturally fermented kvass. Spray drying had a significant influence on the decrease of B vitamins in dry kvass $(p<0.05)$; the highest decrease was observed for niacin $\left(B_{3}\right)$. The content of major sugars was lower in dry kvass based on the dilution by the addition of maltodextrin. 26 different volatile compounds were detected in liquid and dry kvass, total values of peak areas were significantly lower in dry kvass $(p<0.05)$. However, the profile of aroma volatiles in dry kvass demonstrates that it can be used for food flavour enrichment.

\section{Acknowledgment}

The authors would like to thank Fabian Dajnowiec, Department of Food Science; University of Warmia and Mazury in Olsztyn, for valuable assistance during dry kvass production.

\section{References}

1. AOAC (1961) AOAC 961.14, Niacin and Niacinamide in Drugs, Foods, and Feeds. Colorimetric Method. Association of Official Agricultural Chemists, Rockville, USA.

2. AOAC (1971) AOAC 970.65, Riboflavin (Vitamin B2) in Foods and Vitamin Preparations. Fluorometric Method. Association of Official Agricultural Chemists, Rockville, USA.

3. AOAC (1986) AOAC 986.27, Thiamine (Vitamin $\mathrm{B}_{1}$ ) in Milk-Based Infant Formula. Fluorometric Method. Association of Official Agricultural Chemists, Rockville, USA.

4. Asadullah K., Tarar O.M., Ali S.A., Jamil K., Begum A. (2010) Study to evaluate the impact of heat treatment on water soluble vitamins in milk. Journal of the Pakistan Medical Association, Vol. 60 (11), p. 909-912.

5. Barba A.A., d'Amore M., Rispol M., Marra F., Lamberti G. (2014) Microwave assisted drying of banana: effects on reducing sugars and polyphenols contents. Czech Journal of Food Sciences, Vol. 32 (4), p. 369-375.

6. Abubakar H., Jega S.A. (2010) Nutritional Composition of Liquid and Spray-dried Juices of Tamarind and Roselle. Nigerian Journal of Nutritional Sciences, Vol. 31 (10), p. 36-39.

7. Birch A.N., Petersen M.A., Hansen A.S. (2013) The aroma profile of wheat bread crumb influenced by yeast concentration and fermentation temperature. LWT-Food Science and Technology, Vol. 50, p. 480-488.

8. Chidan Kumar C.S., Chandraju S., Mythilya R., Channu B.C. (2011) Novel Spectrophotometric Technique for the Estimation of Reducing Sugar from Wheat Husk. International Journal of Recent Scientific Research, Vol. 2, p. 50-53.

9. FAO (2003) Food energy - methods of analysis and conversion factors: Report of a technical workshop. FAO Food and Nutrition Paper No 77. Rome: Food and Agriculture Organization of The United Nations. 93 p.

10. Grabowskia J.A., Truonga V.D., Daubertb C.R. (2008) Nutritional and rheological characterization of spray dried sweetpotato powder. LWT-Food Science and Technology, Vol. 41, p. 206-216.
11. Fuliaş A., Vlase G., Vlase T., Oneţiu D., Doca N., Ledeti I. (2014) Thermal degradation of B-group vitamins: $B_{1}, B_{2}$ and B6. Journal of Thermal Analysis and Calorimetry. Vol. 118 (2), p. 1033-1038.

12. Oberoi D.P.S., Sogi D.S. (2015) Effect of drying methods and maltodextrin concentration on pigment content of watermelon juice powder. Journal of Food Engineering, Vol. 165, p. 172-178.

13. Gas chromatography - olfactometry of natural products (2004) Flavornet Database. [accessed on 16.03.2017.] Available: http://www.flavornet.org/flavornet.html

14. Goula A.M., Adamopoulos G.K. (2010) A new technique for spray drying orange juice concentrate. Innovative Food Science \& Emerging Technologies, Vol. 11 (2), p. 342-351.

15. Hazelwood L.A., Daran J.M., van Maris A.J.A., Pronk J.T., Dickinson J.R. (2008) The Ehrlich pathway for fusel alcohol production: A century of research on Saccharomyces cerevisiae metabolism. Applied and Environmental Microbiology, Vol. 74, p. 2259-2266.

16. ISO (2000) ISO 7485:2000, Animal feeding stuffs Determination of potassium and sodium contents Methods using flame-emission spectrometry. International Organization for Standardization, Geneva, Switzerland.

17. ISO (2004) ISO 5537:2004, Dried milk - Determination of moisture content (Reference method). International Organization for Standardization, Geneva, Switzerland.

18. ISO (2005) ISO 5983-1:2005, Animal feeding stuffs Determination of nitrogen content and calculation of crude protein content - Part 1: Kjeldahl method. International Organization for Standardization, Geneva, Switzerland.

19. ISO (2015) ISO 12966-4:2015, Animal and vegetable fats and oils - Gas chromatography of fatty acid methyl esters-Part 4: Determination by capillary gas chromatography. International Organization for Standardization, Geneva, Switzerland.

20. Lidums I., Karklina D. (2016) Possibilities of dry kvass for food flavour enrichment. In: 11th International Scientific Conference "Students on their way to science", Collection of abstracts from the 11th International Scientific Conference, Latvia, Jelgava, p. 50.

21. Lidums I., Karklina D., Kirse A. (2014) Quality changes of naturally fermented kvass during production stages. In: 9th Baltic conference on food science and technology "Food for consumer well-being": FOODBALT 2014; Conference proceedings, Latvia, Jelgava, p.188-191.

22. Lidums I., Karklina D., Kirse A. (2016) Characteristics of dry naturally fermented kvass obtained by spray drying. In: 22nd international scientific conference "Research for rural development 2016"; The annual 22nd international scientific conference proceedings, Latvia, Jelgava, Vol. 1, p. 106-110.

23. Lidums I., Karklina D., Sabovics M., Kirse A. (2015) Evaluation of aroma volatiles in naturally fermented kvass and kvass extract. In: 21st international scientific conference "Research for rural development 2015"; The annual 21st international scientific conference proceedings, Latvia, Jelgava, Vol. 1, p. 143-149.

24. Odor Descriptors (2015) The Good Scents Company Infomation System. [accessed on 06.01.2017.] Available: http://www.thegoodscentscompany.com/allord.htm

25. Omasheva A.C., Beisenbayev A.Y., Urazbayeva K.A., Abishev M.J., Beysenbaeva Z.A. (2015) Study on the influence herbal supplements as therapeutic kvass. Technical science, Vol. 5 (1), p. 822-826. 
26. Purlis E. (2010) Browning development in bakery products - a review. Journal of Food Engineering, Vol. 99 (3), p. 239-249.

27. Regulation (EU) No 1169/2011 of the European Parliament and of the Council of 25 October 2011 on the provision of food information to consumers, amending Regulations (EC) No 1924/2006 and (EC) No 1925/2006 of the European Parliament and of the Council, and repealing Commission Directive 87/250/EEC, Council Directive 90/496/EEC, Commission Directive 1999/10/EC, Directive 2000/13/EC of the European Parliament and of the Council, Commission Directives 2002/67/EC and 2008/5/EC and Commission Regulation (EC) No 608/2004 (OJ L 304, 22.11.2011, p. 18-63).

28. Riu-Aumatell M., Miro P., Serra-Cayuela A., Buxaderas S., Lopez-Tamames E. (2014) Assessment of the aroma profiles of low-alcohol beers using HS-SPME-GC-MS. Food Research International, Vol. 56, p. 196-202.

29. Salim E.R.A., Abu-Goukh A-B. A., Hassan El-Subiki Khalid H., El Hassan G.M. (2015) Investigation of Spearmint Carvone and Oil Constituents under Different Drying Methods. Journal of Forest Products \& Industries, Vol. 4 (3), p. 114-121.
30. Tonon R.V., Freitas S.S., Hubinger M.D. (2011) Spray drying of acai (Euterpe oleraceae mart.) juice: effect of inlet air temperature and type of carrier agent. Journal of Food Processing and Preservation, Vol.35(5), p. 691-700.

31. Sedláková J., Kocourková B., Lojková L., Kubáň V. (2003) The essential oil content in caraway species (Carum carvi L.). Horticultural Science, Vol. 30 (2), p. 73-79.

32. USDA National Nutrient Database for Standard Reference. Release 22. [accessed on 12.03.2017.]. Available: http://www.nal.usda.gov/fnic/foodcomp/search/

33. USDA Table of Nutrient Retention Factors. Release 6. [accessed on 16.03.2017.] Available: https://www.ars.usda.gov/ARSUserFiles/80400525/Data/ retn/retn06.pdf

34. ГОСТ (1988) ГОСТ 6687.7-88, Напитки безалкогольные и квасы. Метод определения спирта. Межгосударственный Совет по стандартизации, метрологии и сертификации, Минск, Белоруссия. 